\title{
SIFAT FUNGSIONAL BUBUK IKAN SELAR KUNING (Selaroides leptoleptis)
}

\author{
Nurul Huda*), Fransiska R. Zakaria*), Deddy Muchtadi*) \\ dan Suparno**t)
}

\begin{abstract}
ABSTRAK
Ikan selar kuning (Selaroides leptoleptis) merupakan salah satu jenis ikan berukuran kecil yang pemanfaatannya masih terbatas dalam bentuk segar dan pengeringan secara tradisional. Penelitian untuk mengembangkan teknologi pengolahan akan dapat meningkatkan nilai guna ikan tersebut. Salah satu teknologi pengolahan yang patut mendapatkan perhatian adalah teknologi pengolahan bubuk ikan.

Pada penelitian ini dilakukan analisis komposisi kimia dan sifat fungsional bubuk ikan. Empat jenis bubuk ikan dibuat dari ikan selar kuning yaitu bubuk daging lumat, bubuk konsentrat, bubuk isolat dan bubuk isolat termodifikasi dengan suksinat anhidrida pada tingkat modifikasi 33\%. Hasil penelitian menunjukkan keempat bubuk ikan yang dihasilkan memiliki kadar protein yang tinggi (86-91-96,14\% bb). Perlakuan ekstraksi lemak dengan isopropanol dapat mengurangi kadar lemak hingga 75\%. Walaupun demikian perlakuan ekstraksi lemak akan menurunkan sifat kelarutan, daya serap air, kapasitas buih dan aktivitas emulsi seperti yang ditunjukkan oleh bubuk konsentrat. Bubuk isolat termodifikasi menunjukkan sifat fungsional kelarutan protein, daya serap air, pembentukan gel, pembuihan dan pengemulsian yang melebihi jenis bubuk ikan lainnya.
\end{abstract}

ABSTRACT: Functional properties of fish powder from yellowstrip trevally (Selaroides leptoleptis). By: Nurul Huda, Fransisha R. Zakaria, Deddy Muchtadi and Suparno.

Yellowstrip trevally (Selaroides leptoleptis) is one of the small size marine fish directly consumed and traditionally processed into dry-salted product. Research on its processing technologies can improve its utilization. Fish powder is one of the processed products which may be developed.

The aim of this research is to determine the chemical compositions and functional properties of four types of fish powder. These properties are solubility, water absorbtion, foaming, emulsification and gelation. The types of fish powder are fish minced, concentrate, isolate and isolate powder modified with succinic anhydride at 33\% modification level. The result showed that all fish powder contained high quantity of protein $(86,91-96,14 \% \mathrm{wb})$. Fat extraction with isopropanol treatment can reduce about $75 \%$ fat content. However, fat extraction causes negative effects on solubility, water absorbtion, foaming and emulsification of the concentrate powder. The isolate modified powder relatively had better properties than the others.

KEYWORDS: fish powder, functional properties, yellowstrip trevally.

\section{PENDAHULUAN}

Produk makanan berbentuk bubuk yang memiliki kadar air yang rendah mempunyai beberapa kelebihan antara lain kemudahan dalam pengangkutan, penyimpanan dan penggunaan yang lebih luas. Produk makanan berbentuk bubuk juga tidak memerlukan suhu rendah untuk mempertahankan mutunya sehingga akan mengurangi biaya bagi penyediaan peralatan. $\mathrm{Hal}$ yang demikian juga berlaku bagi produk makanan berbentuk bubuk yang diproses dari ikan.

\footnotetext{
*) Pengajar pada Fakultas Perikanan Univ. Bung Hatta, Padang

**) Pengajar pada Fakultas Teknologi Pertanian, IPB

***) Peneliti pada Balai Penelitian Perikanan Laut
} 
Kemungkinan pengolahan bubuk ikan bagi konsumsi manusia masih merupakan objek yang perlu diteliti (Purwaka, 1994; Suparno \& Dwiponggo, 1994). Supaya dapat dikonsumsi manusia, bubuk ikan yang dihasilkan di samping memiliki nilai gizi yang tinggi juga harus memiliki sifat-sifat fungsional yang baik. Sifat fungsional ini merupakan sifat selain nilai gizi yang mempengaruhi penerimaan pancaindera terhadap suatu makanan dan terutama sekali menyangkut sifat fisikokimia protein. Beberapa sifat fungsional yang penting dalam sistem makanan adalah sifat kelarutan, penyerapan air, pembentukan gel, pembentukan buih dan emulsifikasi (Cheftel et al., 1985).

Protein ikan merupakan kelompok protein yang pada awalnya memiliki sifat fungsional yang baik, tetapi perlakuan selama pengolahan dapat menyebabkan terjadinya perubahan yang mengarah pada penurunan sifat fungsional tersebut. Perlakuan panas yang berlebihan dan penggunaan pelarut organik dapat menyebabkan menurunnya sifat fungsional protein pada bubuk ikan. Peningkatan sifat fungsional protein pada bubuk ikan dapat dilakukan dengan menggunakan metode pengeringan yang lebih baik dan dapat juga dilakukan dengan menambahkan zat kimia tertentu. Suksinat anhidrida merupakan salah satu zat kimia yang dapat digunakan untuk memperbaiki sifat fungsional protein ikan. Penambahan zat kimia suksinat anhidrida telah menunjukkan perbaikan sifat-sifal fungsional pada bubuk ikan Rockfish (Groniger, 1973) dan bubuk miofibril jantung sapi (Eiselle \& Brekke, 1981).

\section{BAHAN DAN METODE}

Bahan yang digunakan dalam penelitian adalah ikan selar kuning (Selaroides leptoleptis) berukuran panjang antara $14,50-16,75 \mathrm{~cm}$. Ikan diambil dari Muara Angke, Jakarta dibawa dalam keadaan segar dalam boks es dengan hancuran es untuk mempertahankan suhu rendah selama transportasi. Zat modifikasi protein yang digunakan adalah suksinat anhidrida keluaran Sigma, USA. Ekstraksi lemak dilakukan dengan menggunakan pelarut isopropanol. Bahan kimia lain yang digunakan adalah bahan kimia bagi analisis komposisi kimia dan sifat fungsional protein.

Sebelum diolah bagian daging ikan dipisahkan dari bagian tubuh lainnya dengan meng- gunakan alat pemisah daging Bibun Co. Ltd. Fukuyama, Japan menjadi daging lumat yang kemudian diolah menjadi empat jenis bubuk yaitu bubuk daging lumat, bubuk konsentrat, bubuk isolat dan bubuk isolat termodifikasi. Diagram alir pengolahan bubuk tersebut dapat dilihat pada Lampiran 1, 2 dan 3.

Bubuk yang didapatkan kemudian dianalisis komposisi kimia dan sifat fungsionalnya. Analisis kadar air, abu, lemak dan protein dilakukan dengan metode AOAC (1984). Sifat fungsional yang diuji adalah kelarutan protein, daya serap air dengan metode Miller \& Groniger (1976), kapasitas buih dan stabilitas buih dengan metode Groniger \& Miller (1979), pembentukan gel dengan metode Cattimpoolas \& Meyer (1970) serta aktivitas dan stabilitas emulsi dengan metode Yasumatsu et al. (1972). Tingkat modifikasi protein oleh penambahan suksinat anhidrida ditentukan dengan metode Kakade \& Linier (1969).

Data yang didapatkan dianalisis dengan menggunakan Rancangan Acak Lengkap dengan enam perlakuan. Perlakuan tersebut adalah empat jenis bubuk ikan (bubuk daging lumat, bubuk konsentrat, bubuk isolat dan isolat termodifikasi) dan dua jenis bubuk pembanding (putih telur dan kasein).

\section{HASIL DAN PEMBAHASAN}

Komposisi kimia berbagai bubuk ikan yang dihasilkan ternyata berbeda-beda berdasarkan proses pembuatannya. Lebih jelas komposisi kimia tersebut dapat dilihat pada Tabel 1.

Suparno \& Dwiponggo (1994) menyatakan bahwa konsentrat protein ikan dapat dikelompokkan atas tiga tipe yaitu tipe A, B dan C. Tipe A dan $\mathrm{B}$ adalah konsentrat yang memiliki kadar lemak lebih rendah dari $3 \%$, sedangkan tipe $\mathrm{C}$ memiliki kadar lemak 3\% hingga 10\%. Berdasarkan hal tersebut bubuk daging lumat termasuk pada tipe $\mathrm{C}$, sedangkan bubuk konsentrat, isolat dan isolat termodifikasi termasuk pada tipe A atau B.

Penggunaan isopropanol dapat mengurangi kadar lemak dari $8,03 \%$ menjadi $1,99 \%$. Dengan demikian sekitar $75 \%$ dari jumlah lemak total dapat dipisahkan oleh pelarut tersebut. Penurunan kadar lemak ini akan meningkatkan kadar protein pada bubuk konsentrat, isolat dan isolat termodifikasi. 
Sifat fungsional protein masing-masing bubuk ikan yang dihasilkan berbeda-beda berdasarkan jenis bubuknya. Hasil analisis sifat fungsional protein kelarutan, daya serap air dan pembentukan gel dapat dilihat pada Tabel 2 .

Pengujian statistik menunjukkan adanya pengaruh yang sangat nyata berdasarkan jenis bubuk yang diuji terhadap sifat kelarutan dan daya serap air. Uji perbandingan Tukey menunjukkan perbedaan kelarutan terdapat pada semua bubuk, kecuali pada bubuk konsentrat dan isolat. Protein pembanding yaitu kasein dan putih telur merupakan protein yang paling larut dalam air. Kelarutan protein ikan lebih rendah dari protein pembanding. Hail ini disebabkan protein ikan umumnya terdiri atas protein tak larut air. Dalam pengolahan bubuk ikan, dilakukan proses pencucian yang menyebabkan banyak terjadi kehilangan protein larut air. Bubuk isolat merupakan bubuk yang paling sedikit larut dalam air. Hal tersebut disebabkan karena komponen utama dalam bubuk isolat adalah protein miofibril. Protein miofibril secara alami merupakan protein yang tidak larut dalam air dan hanya larut dalam larutan garam.

Tabel 1. Komposisi kimia berbagai bubuk ikan selar kuning (\% bb).

Table 1. Chemical composition of yellowstrip trevally fish powder $(\% \mathrm{wb})$.

\begin{tabular}{lcccc}
\hline \multicolumn{1}{c}{$\begin{array}{c}\text { Jenis Bubuk } \\
\text { Kinds of Fish Powder }\end{array}$} & $\begin{array}{c}\text { Air } \\
\text { Moisture }\end{array}$ & $\begin{array}{c}\text { Protein } \\
\text { Protein }\end{array}$ & $\begin{array}{c}\text { Lemak } \\
\text { Fat }\end{array}$ & $\begin{array}{c}\text { Abu } \\
\text { Ash }\end{array}$ \\
\hline Daging Lumat (Minced powder) & 3.45 & 86.91 & 8.03 & 2.96 \\
Konsentrat (Concentrate powder) & 4.93 & 90.99 & 1.99 & 2.23 \\
Isolat (Isolate powder) & 1.89 & 96.14 & 1.08 & 1.99 \\
Isolat termodifikasi (Isolate modified & 1.22 & 95.85 & 0.99 & 1.11 \\
powder) & & & & \\
\hline
\end{tabular}

Tabel 2. Sifat fungsional kelarutan, daya serap air dan pembentukan gel bubuk protein ikan dan pembandingnya.

Table 2. Functional properties of solobulity, water absorbtion and gelation of fish powder and their references.

\begin{tabular}{|c|c|c|c|}
\hline $\begin{array}{c}\text { Jenis Bubuk } \\
\text { Kind of Powder }\end{array}$ & $\begin{array}{c}\text { Kelarutan } \\
\text { Protein (\%) } \\
\text { Protein } \\
\text { Solubility } \\
\end{array}$ & $\begin{array}{c}\text { Daya Serap } \\
\text { Air (mL/g) } \\
\text { Water } \\
\text { Absorbtion } \\
\end{array}$ & $\begin{array}{l}\text { Pembentukan } \\
\text { Gel (\% protein) } \\
\text { Gel Formation }\end{array}$ \\
\hline Daging lumat (Minced powder) & $8,06^{a}$ & $8,70^{\mathrm{a}}$ & . \\
\hline Konsentrat (Concentrate powder) & $1,91^{1}$ & $5,00^{1}$ & - \\
\hline Isolat (Isolate powder) & $1,45^{1,}$ & $7,50^{\mathrm{a}}$ & - \\
\hline $\begin{array}{l}\text { Isolat termodifikasi (Isolate modified } \\
\text { powder) }\end{array}$ & $14,07^{\prime}$ & $30,50^{c}$ & $3 \%$ \\
\hline Putih Telur (Albumen) & $65.31^{\text {th }}$ & $1.75^{4}$ & $1 \%$ \\
\hline Kasein (Casein) & $75,71^{\prime}$ & $2,50)^{\prime}$ & \\
\hline
\end{tabular}

* Angka dengan notasi huruf yang sama tidak menunjukkan perbedaan pada uji Tukey 0,05

*Values in collums followed by the same superscript arr not significantly diferrent at 0.05 tukey test 
Adanya tambahan tahapan suksinilasi pada bubuk modifikasi memberikan pengaruh yang besar terhadap peningkatan kelarutan protein dibandingkan bubuk tanpa modifikasi. Peningkatan kelarutan protein yang disuksinilasi merupakan pencerminan dari reaksi yang terjadi antara suksinat anhidrida dan gugus e-amino lisin membentuk suksinillisin yang menimbulkan perubahan muatan asam amino menjadi bermuatan negatif satu; perubahan konformasi protein dan adanya peningkatan kecenderungan protein untuk terdisosiasi menjadi sub-sub unit (Frazen \& Kinsella, 1976).

Habeeb et al. (1958) mengemukakan sebagai adanya gugus karboksil bermuatan negatif dari hasil suksinilasi, maka gaya tarik menarik elektrostatik di antara protein akan berubah menjadi gaya tolak menolak elektrostatik antara gugus karboksil yang bertetangga. Hal ini lebih lanjut merangsang terjadinya pembukaan lipatan (unfolding) dan penyusunan semula (rearrangement) dari rantai polipeptida. Perubahan tersebut menyebabkan terbentuknya konfigurasi protein yang baru seperti tereksposnya keluar rantai asam amino polar yang sebelumnya terlindung dalam struktur tersier protein. Akibat akhirnya adalah menurunnya interaksi protein-protein dan meningkatnya interaksi antara protein-air yang akan mengubah sifat kelarutannya.

Bubuk daging lumat memiliki daya serap air yang lebih besar dibandingkan dengan bubuk konsentrat. Pada bubuk konsentrat, adanya perlakuan pemisahan protein sarkoplasma yang banyak mengandung gugusan hidrofilik menyebabkan berkurangnya sifat hidrofilisitas sehingga menurunkan kemampuan untuk menarik air. Hal ini ditambah lagi dengan adanya perlakuan ekstraksi lemak dengan pelarut isopropanol dapat mengurangi sifat hidrofilisitas melalui de. naturasi. Kontak antara pelarut organik dengan protein dapat menimbulkan terjadinya denaturasi (Winarno, 1991).

Dari Tabel 2 diketahui juga bahwa bubuk isolat termodifikasi memiliki daya serap air yang lebih besar dibandingkan dengan bubuk lainnya. Modifikasi protein ikan dengan suksinat anhidrida dapat mengakibatkan terjadinya peningkatan kemampuan menyerap air. Peningkatan kemampuan menyerap air ini merupakan akibat dari bertambahnya gugus hidrofilik dan ber. kurangnya gugus hidrofobik protein sebagai akibat terbentuknya suksinillisin. Tingkat hidrofobisitas protein akan menurun jika dilakukan suksinilasi. Protein pembanding yang digunakan yaitu protein putih telur dan kasein memiliki kemampuan menyerap air yang paling rendah.

Bubuk isolat termodifikasi dan putih telur merupakan bubuk yang mempunyai kemampuan membentuk gel. Kemampuan bubuk putih telur membentuk gel lebih tinggi dibandingkan dengan kemampuan bubuk isolat termodifikasi, di mana pada konsentrasi $1 \%$.telah membentuk gel, sedangkan pada protein isolat termodifikasi baru dapat membentuk gel pada konsentrasi $3 \%$.

Miller \& Groniger (1976) juga menemukan hasil yang sama pada bubuk isolat termodifikasi spesies ikan Sebastes sp. Mekanisme pembentukan gel pada protein ikan yang disuksinilasi belum banyak diteliti. Interaksi yang berperanan dalam pembentukan gel adalah interaksi elektrostatik, hidrofobik dan disulfida. Ikatan disulfida mempunyai kekuatan yang besar bagi terbentuknya gel. Suksinilasi walaupun terutama sekali terikat pada gugus e-amino lisin, namun dilaporkan juga terikat pada gugus sulfihidril (Habeeb et al., 1958). Akan tetapi ikatan dengan gugus sulfihidril tersebut kekuatannya rendah dan dapat terhidrolisa kembali (Feeney et al., 1982). Adanya perlakuan pelarutan protein dalam air, pengadukan dan pemanasan selama proses pengujian pembentukan gel dapat menimbulkan akibat terjadinya hidrolisis suksinilsistein. Terlepasnya suksinat dari sistein menyebabkan terbentuknya kembali ikatan sulfihidril. Pembentukan ikatan sulfihidril tersebut akan menjadikan cairan yang ada di sekelilingnya terperangkap. Jika seluruh cairan dapat terperangkap, maka gel akan terbentuk.

Sifat-sifat fungsional protein lainnya yaitu kapasitas buih, stabilitas buih, aktivitas emulsi dan stabilitas emulsi ternyata juga berbeda-beda berdasarkan metode pengolahan yang dilakukan. Hasil analisis sifat fungsional tersebut dapat dilihat pada Tabel 3.

Dari tabel tersebut diketahui bahwa bubuk isolat termodifikasi memiliki sifat pembuihan dan pengemulsian yang lebih baik dibandingkan dengan bubuk ikan lainnya. Stabilitas buih dan stabilitas emulsi dari keempat jenis bubuk ikan adalah tinggi. Pada kasein, walaupun memiliki kapasitas buih yang tinggi, stabilitas buih adalah 
Tabel 3. Sifat fungsional pembuihan dan pengemulsian bubuk protein ikan dan pembandingnya. Table 3. Functional properties of foaming and emulsion of fish powder and their references.

\begin{tabular}{|c|c|c|c|c|}
\hline $\begin{array}{l}\text { Jenis Bubuk } \\
\text { Kind of Powder }\end{array}$ & $\begin{array}{c}\text { Kapasitas } \\
\text { Buih }(\%) \\
\text { Foam } \\
\text { Capacity } \\
\end{array}$ & $\begin{array}{c}\text { Stabilitas } \\
\text { Buih (\%) } \\
\text { Foam } \\
\text { Stability } \\
\end{array}$ & $\begin{array}{c}\text { Aktivitas } \\
\text { Emulsi (\%) } \\
\text { Emulsion } \\
\text { Activity } \\
\end{array}$ & $\begin{array}{c}\text { Stabilitas } \\
\text { Emulsi (\%) } \\
\text { Emulsion } \\
\text { Stability } \\
\end{array}$ \\
\hline Daging lumat (Minced powder) & $21.00^{\mathrm{n}}$ & $80.02^{\mathrm{a}}$ & $28.35^{\mathrm{a}}$ & $90.17^{\text {a }}$ \\
\hline Konsentrat (Concentrate powder) & $7.50^{\mathrm{b}}$ & $83.33^{n}$ & $3.16^{\mathrm{b}}$ & $89.21^{\mathrm{a}}$ \\
\hline Isolat (Isolate powder) & $10.00^{c}$ & $85.18^{a}$ & $10.83^{\mathrm{c}}$ & $79.63^{\mathrm{b}}$ \\
\hline $\begin{array}{l}\text { Isolat termodifikasi (Isolate } \\
\text { modified powder) }\end{array}$ & $27.50^{\text {d }}$ & $92.51^{\mathrm{b}}$ & $99.00^{d}$ & $95.76^{\text {a }}$ \\
\hline Putih telur (Albumen) & $23.00^{\text {and }}$ & $92.26^{\mathrm{b}}$ & $72.97^{\mathrm{e}}$ & $125.98^{c}$ \\
\hline Kasein (Casein) & $110.50^{\circ}$ & $14.03^{\circ}$ & $90.73^{\mathrm{d}}$ & $95.97^{\mathrm{a}}$ \\
\hline
\end{tabular}

*Angka dengan notasi huruf yang sama tidak menunjukkan perbedaan pada uji Tukey 0,05

*Values in collums followed by the same superseript are not significantly diferrent at 0.05 Tukey test

rendah dikarenakan buih yang terbentuk besarbesar dan dengan cepat memecah. Pada bubuk putih telur, pengujian stabilitas emulsi memberikan nilai yang lebih besar dibandingkan dengan aktivitas emulsinya. Hal ini adalah sesuatu hal yang menarik. Kemungkinan pemanasan yang diberikan semasa pengujian stabilitas emulsi menyebabkan protein yang terdapat dalam bubuk putih telur mengalami pengembangan atau menjadikan partikel air yang berada di sekitarnya terperangkap.

Pada bubuk daging lumat, kapasitas buih dan aktivitas emulsi lebih tinggi dari bubuk konsentrat dan bubuk isolat. Hal ini disebabkan oleh masih terdapatnya protein sarkoplasma yang larut air dalam produk tersebut. Ketergantungan pembentukan buih dari protein sarkoplasma tersebut merupakan pencerminan hubungan kelarutan protein terhadap pembentukan buih. Semakin tinggi kelarutan protein tersebut dalam air, maka kapasitas buih yang terbentuk akan semakin besar (Cheftel et al., 1985).

Penambahan zat suksinat anhidrida pada isolat protein ikan ternyata dapat meningkatkan sifat fungsional kapasitas buih dan aktivitas emulsi berbanding tepung isolat saja. Peningkatan kapasitas buih adalah sebesar $175 \%$, sedangkan aktivitas emulsi mencapai $8141 \%$. Sementara itu stabilitas buih dan emulsi yang terbentuk juga ditingkatkan melalui penambahan zat suksinat anhidrida. Peningkatan sifat pembuihan dan pengemulsian sebagai akibat dilakukannya suksinilasi juga ditemukan pada protein ikan Sebastes sp. (Miller \& Groniger, 1975), kedele (Frazen \& Kinsella, 1976) dan protein miofibril jantung sapi (Eiselle \& Brekke, 1981).

Aktivitas emulsi akan terbentuk optimum apabila terdapat keseimbangan antara gugus hidrofobik dan gugus hidrofilik. Protein pada produk tanpa modifikasi mungkin memiliki gugus hidrophobik yang dominan. Suksinilasi yang dilakukan mungkin menyebabkan terjadinya pembukaan lipatan (unfolding) dan penyusunan semula (rearrangement) yang berakibat tereksposnya ke gugus hidrofilik. Hal ini ditambah lagi dengan terbentuknya gugus karboksil hasil suksinilasi yang juga bersifat hidrofilik. Faktor tersebut dapat menghasilkan rangkaian konfigurasi molekul yang meningkatkan sifat hidrofilisitas (Frazen \& Kinsella, 1976). Pentingnya keseimbangan gugus hidrofobik dan hidrofilik ini disebabkan gugus hidrofobik mempunyai afinitas terhadap minyak, sedangkan gugus hidrofilik mempunyai afinitas terhadap air. Butir-butir minyak akan diselubungi sehingga mencegah bersatunya kembali butir-butir minyak tersebut (Winarno, 1991).

\section{KESIMPULAN DAN SARAN}

Dari daging lumat ikan selar kuning dapat diolah menjadi berbagai jenis bubuk ikan yang memiliki kadar protein yang tinggi. Bubuk daging lumat memiliki kadar protein kasar adalah $86,91 \%$ bb; bubuk konsentrat adalah $90,99 \%$ bb dan bubuk isolat adalah $96,14 \%$ bb. Modifikasi 
dengan suksinilasi menghasilkan bubuk isolat termodifikasi dengan kadar protein $95,85 \%$ bb. Bubuk isolat termodifikasi menunjukkan sifatsifat fungsional paling baik dari jenis bubuk ikan lainnya. Sifat-sifat fungsional tersebut mencakup kelarutan protein $14,07 \%$; daya serap air 30,50 $\mathrm{mL} / \mathrm{g}$ protein, mampu membentuk gel pada konsentrasi protein $3 \%$, kapasitas buih $27,50 \%$, stabilitas buih $92,5 \%$, aktivitas emulsi $99,00 \%$ dan stabilitas emulsi $95,76 \%$. Pada beberapa sifat fungsional yaitu daya serap air, pembentukan gel dan aktivitas emulsi, bubuk isolat termodifikasi lebih baik dibandingkan dengan bubuk kasein.

Walaupun bubuk isolat termodifikasi dengan suksinilasi menunjukkan sifat-sifat fungsional yang lebih baik dari jenis bubuk ikan lainnya, bahkan menunjukkan kelebihan dibandingkan bubuk kasein dan bubuk putih telur, akan tetapi mutu protein baik secara in vivo maupun in vitro perlu untuk diperhatikan lebih lanjut. Penerapan dalam sistem makanan dan aspek kesehatan dari penggunaan suksinat memerlukan penelitian yang lebih mendalam agar penerapan bubuk isolat termodifikasi tersebut dalam formulasi makanan jadi dapat dipastikan memberikan sumbangan yang baik bagi pemenuhan gizi manusia.

\section{DAFTAR PUSTAKA}

AOAC. 1984. Official methods of analysis of the association of official chemist. AOAC, Inc. Arlington. Virginia.

Catsimpoolas, N and E. W. Meyer. 1970. Gelation phenomena of soybean globulin. Cereal Chem. 214:559.

Cheftel, J. C., J. L. Cug and D. Lorient. 1985. Amino acid, peptides and proteins. In O. R. Fennema (ed.). Food Chemistry: 2"11, Revised and Expanded. Marcell Dekker Inc., New York. hal. 245-370.

Eiselle, T. A. and C. J. Brekke. 1981. Chemical modification and functional properties of acylated beef heart myofibrillar proteins. J. Food Sci. 46:10951102.

Feeney, R. E, R. B. Yamasaki and K. F. Geoghegan. 1982. Chemical modification of protein: An Overview. In R. E. Feeney and J. R. Whitaker (eds.). Modification of Protein: Food, Nutritional and Pharmacological Aspects. Amer. Chem. Soc. Washington. 3-56.

Frazen, K. C. and J. E. Kinsella. 1976. Functional properties of succinylated and acetylated soy protein. J. Agr. Food Chem. 24:788-795.

Groniger, H. S. 1973. Preparation and properties of succinylated fish miofibrillar proteins. J. Agr. Food Chem. 21:978-981.

Groniger, H. S., and R. Miller. 1979. Some chemical and nutritional properties of acylated fish protein. J. Agric. Food Chem. 27:949-955

Habeeb, A. F. S. A., H. Cassidy and S. Singer. 1958. Molekuler structural effect produced in protein by reaction with succinic anhidride. Biochem. Biophys. Acta. 29:589-561.

Kakade, M. J. and I. E. Liener. 1969. Determination of available lysine in proteins. Anal. Biochem. 27:273280 .

Miller, R. and H. S. Groniger. 1976. Functional properties of enzyms modified acylated fish protein derivates. J. Food Sci. 41:268-272.

Purwaka, T. H. 1994. Potensi dan permasalahan pengembangan produksi pangan dari sumber hayati laut Indonesia. Dalam M. A. Rifai (eds.). Risalah Widyakarya Pangan dan Gizi V. LIPI, Jakarta. 176-212.

Suparno dan Dwiponggo, A. 1994. Ikan-ikan yang kurang dimanfaatkan sebagai bahan pangan bergizi tinggi. Dalam M. A. Rifai (eds.). Risalah Widyakarya Pangan dan Gizi V. LIPI, Jakarta. 213227.

Winarno, F.G. 1991. Kimia pangan dan gizi. Gramedia, Jakarta. 252 hal.

Yasumatsu, K., K. Sawada, S. Moritaka, M. Misaki, J. Toda, T. Wada and K. Ishi. 1972. Whipping and emulsion properties. Agric. Biol. Chem. 36:719. 
Lampiran 1. Diagram alir pengolahan bubuk daging lumat.

Appendix 1. Flow diagram of minced fish powder processing.

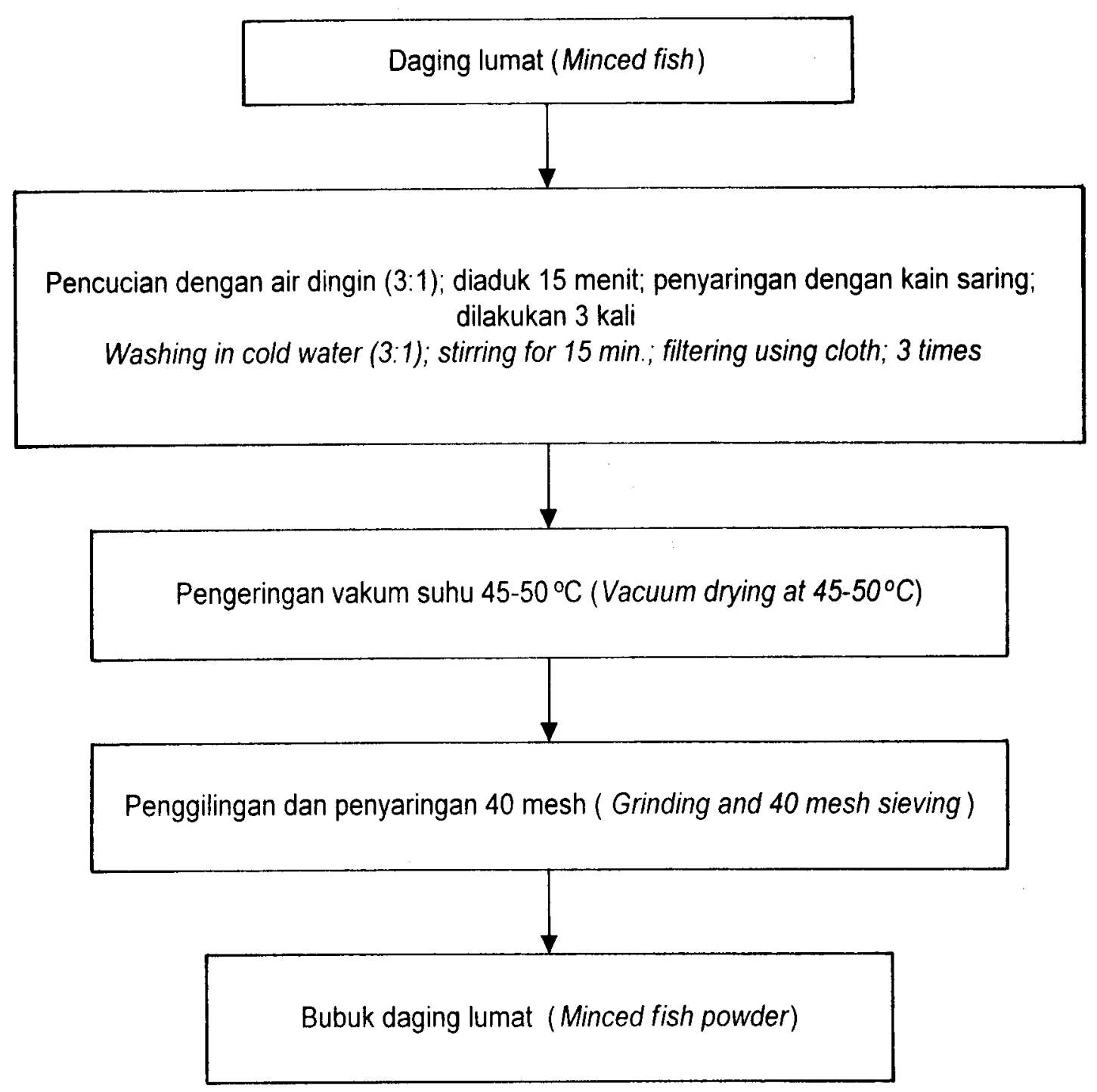


Huda, N.; F.R. Zakaria; D. Muchtadi; dan Suparno

Lampiran 2. Diagram alir pengolahan bubuk konsentrat.

Appendix 2. Flow diagram of fish concentrated powder processing.

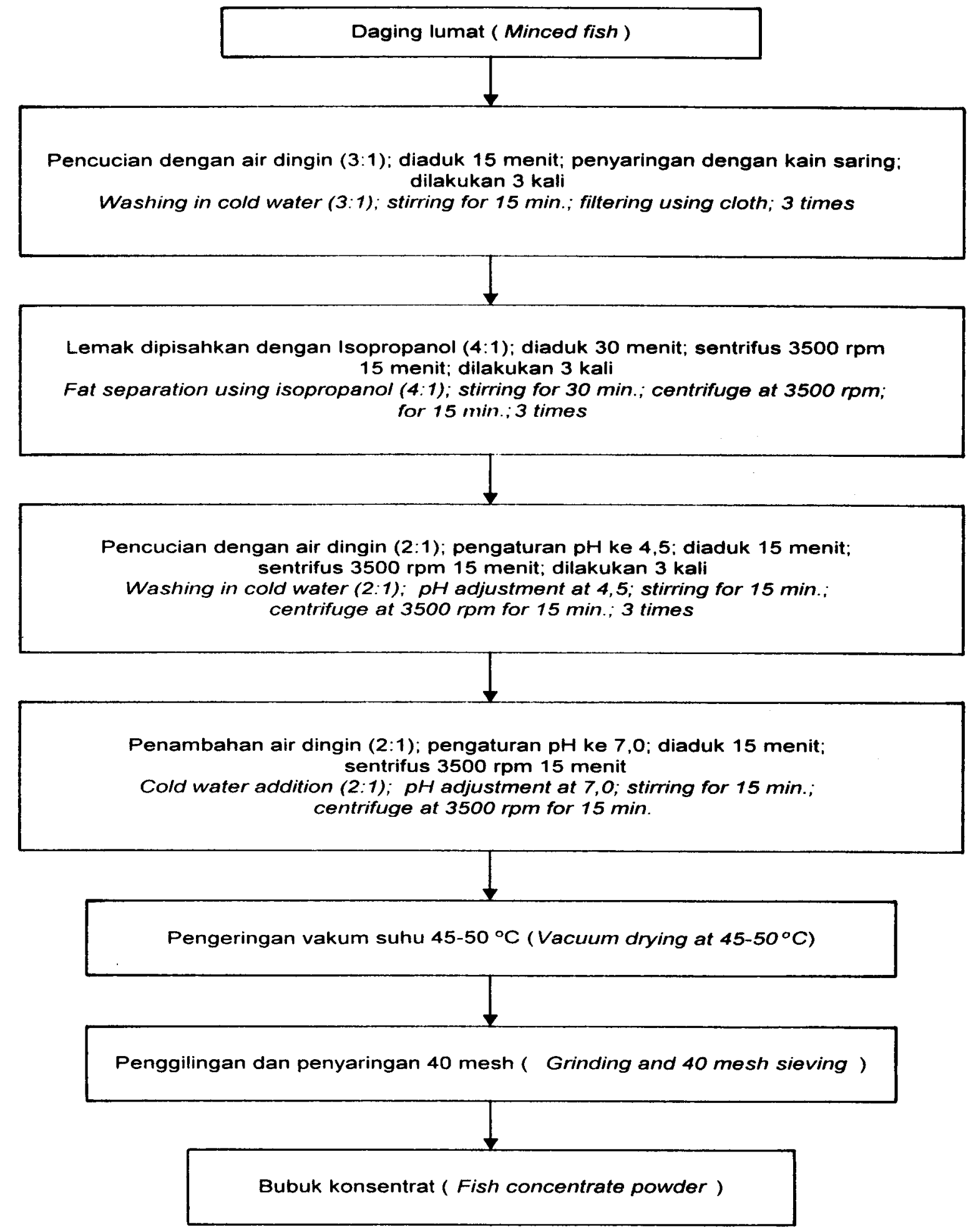


Lampiran 3. Diagram alir pengolahan bubuk isolat dan isolat termodifikasi.

Appendix 3. Flow diagram of fish powder and powder fish isolate powder processing.

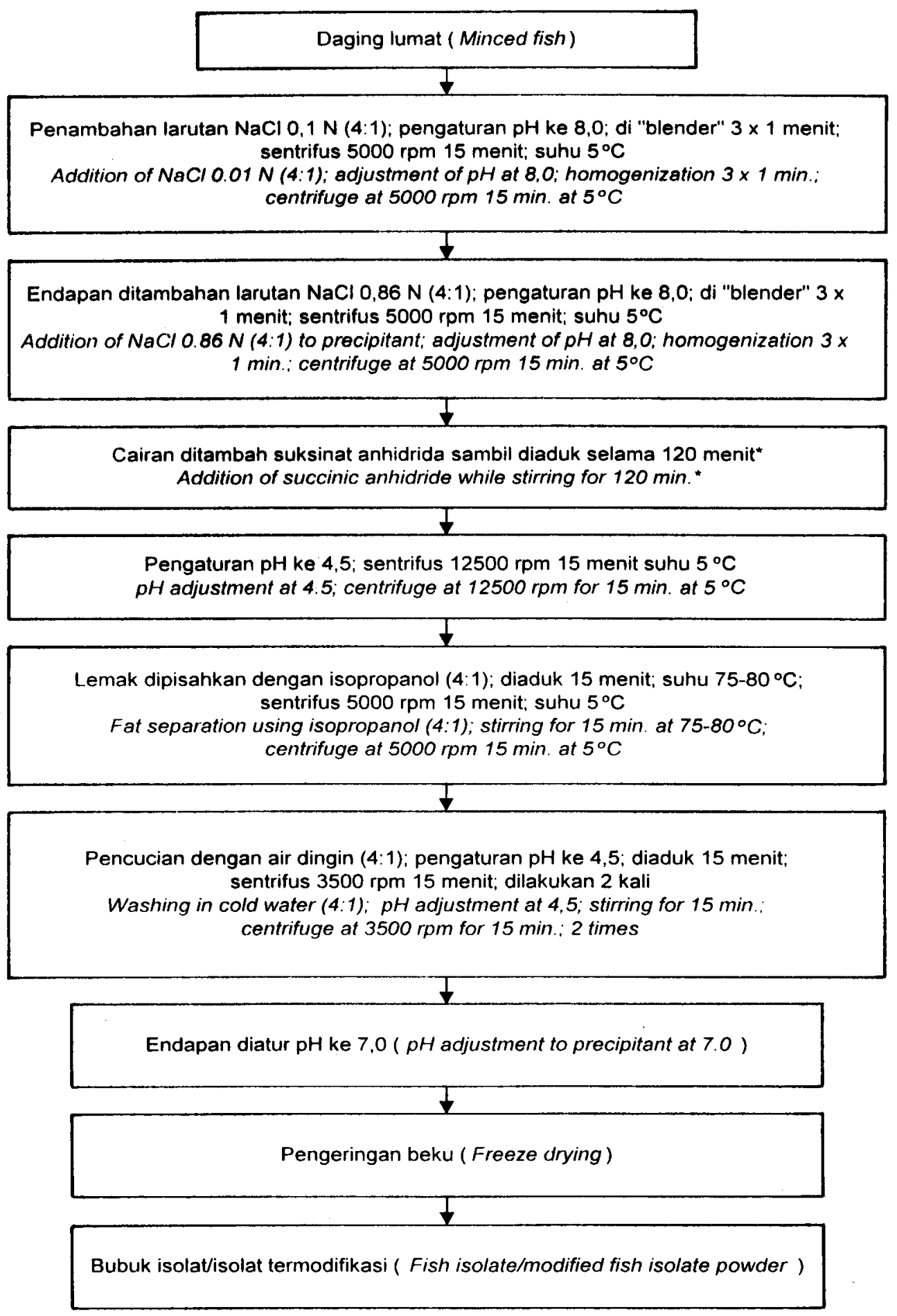

